
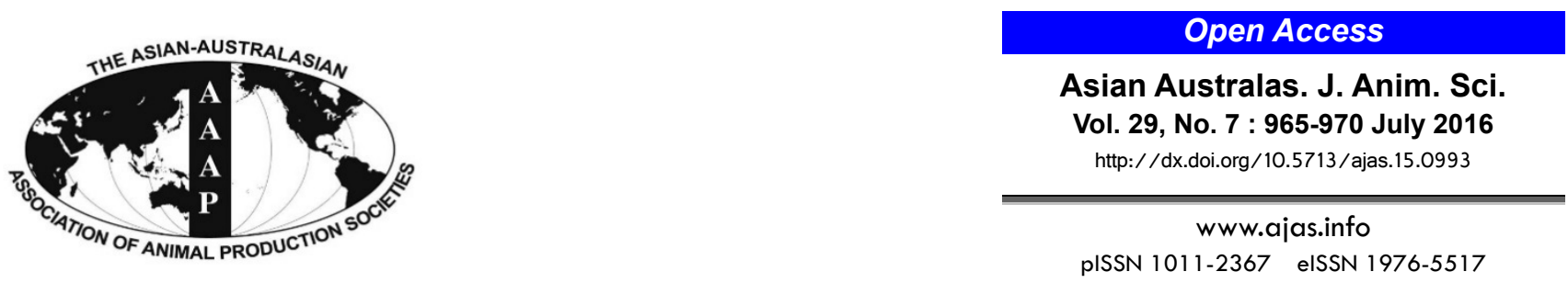

\title{
The Effects of Freezing and Supplementation of Molasses and Inoculants on Chemical and Nutritional Composition of Sunflower Silage
}

\author{
Y. Konca, S. Buyukkilic Beyzi*, T. Ayaşan', M. Kaliber, and A. Bozkurt Kiraz² \\ Agricultural Faculty, Animal Science Department, Erciyes University, Kayseri 38039, Turkey
}

\begin{abstract}
This study was conducted to determine the effects of freezing and supplementation of molasses (M), lactic acid bacteria (LAB) and LAB+enzyme mixture on chemical and nutritional composition of sunflower silage (SF). Sunflower crops were harvested (at about $29.2 \% \pm 1.2 \%$ dry matter) and half of fresh sunflower was ensiled alone and half was frozen (F) at $-20^{\circ} \mathrm{C}$ for 7 days. Silage additives were admixed into frozen SF material. All samples were ensiled in glass jars with six replicates for 90 days. The treatments were as follows: i) positive control (non-frozen and no additives, NF), ii) negative control (frozen, no additives, F), iii) $\mathrm{F}+5 \%$ molasses (FM), iv) F+LAB (1.5 g/tons, Lactobacillus plantarum and Enterococcus faecium, FLAB); v) F+LAB+enzyme (2 g/tons Lactobacillus plantarum and Enterococcus faecium and cellulase and amylase enzymes, FLEN). Freezing silage increased dry matter, crude ash, neutral detergent fiber, and acid detergent lignin. The organic matter, total digestible nutrient, non-fiber carbohydrate, metabolizable energy and in vitro dry matter digestibility were negatively influenced by freezing treatments $(\mathrm{p}<0.05)$. In conclusion, freezing sunflower plants prior to ensiling may negatively affect silage quality, while molasses supplementation improved some quality traits of frozen silage. Lactic acid bacteria and LAB+enzyme inoculations did not effectively compensate the negative impacts of freezing on sunflower silage. (Key Words: Enzyme, Freezing, Lactobacillus Bacteria, Molasses, Sunflower Silage)
\end{abstract}

\section{INTRODUCTION}

Sunflower is generally planted for seed production; however the green sunflower plant is also used as silage and forage by livestock producers. Sunflower is known to be drought and cold-resistant, therefore it can be planted as both first and second crop (Tan et al., 2015). The high fiber content of sunflower silage decreases digestibility of nutrients and low dry matter content at maturity makes ensilage difficult (Demirel et al., 2006).

Silage plants, cultivated as a second crop, are usually harvested and ensiled in fall. However, in recent years due to global climate changes, silage crops may sometimes freeze either before the harvest or after ensilage. Thus,

\footnotetext{
* Corresponding Author: S. Buyukkilic Beyzi. Tel: +90352-2076666 (38578), Fax: +90352-4376209, E-mail: sbuyukkilic@hotmail.com

${ }^{1}$ East Mediterranean Agricultural Research Institute, Adana 01321, Turkey.

2 Agricultural Faculty, Animal Science Department, Harran University, Şanlıurfa 38039, Turkey.

Submitted Dec. 4, 2015; Revised Jan. 18, 2016; Accepted Feb. 29, 2016
}

plants are frozen in some cases before sufficient fermentation was achieved. With freezing, ice crystals may result in physical and microbiological spoilage of the silage. Freezing reduces water activity, increases intracellular solute concentration, promotes protein degradation, decreases $\mathrm{pH}$ levels, and initiates a thermal shock on microorganisms (Speck and Ray, 1977). All these events ultimately affect the maturation of ensilaged material and may alter chemical and nutrient composition of the silage. Together with freezing, enormous changes are observed in lipid oxidation, enzymatic esterification, taste, protein degradation, cellulose content, loss of pigments and vitamins (Fennoma and Powrie, 1963).

At slow freezing rates $(0.2$ to $1 \mathrm{~cm} / \mathrm{h})$, ice crystals grow slowly and settle in the vacuoles of feed. This can damage the cell wall and alter consequently the shape is distorted and degradation is accelerated (Martino and Zaritzky, 1988). Freeze and thaw cycles may also breakup the cell walls and release non-nutritious and toxic substances (Gleadow et al., 2012). Such cycles particularly alter cellulose content of the silage. However, such a condition may vary based on 
soluble protein concentrations during thawing. Similarly, severe water losses occur during thawing and dehydration of water-soluble substances resulting in significant losses of carbohydrates. Such conditions ultimately lead to loss of energy and carbohydrates due to reductions in total digestible nutrients (TDN) of feeds (Martino and Zaritzky, 1988).

On the other hand, when the plants freeze, certain bacteria and other microorganisms naturally present in plant may be killed by freezing temperatures. So, following the freezing process, microbial fermentation and thus the silage quality will be altered. Freezing is usually applied under laboratory conditions to preserve the silage samples until analysis.

The present study was conducted to determine the effects of slow freezing $(0.2$ to $1 \mathrm{~cm} / \mathrm{h})$ and different supplements on chemical and nutritional composition of frozen sunflower silage.

\section{MATERIALS AND METHODS}

\section{Experimental designs and procedures}

Sunflower (Helianthus annuus L.) plants were grown over the experimental fields of Erciyes University Agricultural Research and Implementation Center (ERUTAM) between May 21 and September 17, 2013. Sunflowers were harvested and chopped in 1.5 to $3 \mathrm{~cm}$ pieces using a conventional corn silage machine (Çelikel Challenger, Turkey). A portion of fresh silage material was ensiled directly in 2-liter glass jars in 6 replications without any treatment to create positive control group, and another portion refrigerated at $-20^{\circ} \mathrm{C}$ for 7 days in a plastic bag $(45 \times 45 \mathrm{~cm})$, then ensiled alone or with additives. This freezing process is called a slow freezing. In brief, materials were frozen 0.2 to $1 \mathrm{~cm}$ per hour at $-10^{\circ} \mathrm{C}$ to $-20^{\circ} \mathrm{C}$ with still air freezers and cold stores type freezers (George, 1993). After seven days, frozen bags were thawed at $+4^{\circ} \mathrm{C}$ and immediately mixed with additives and filled two lt glass jars with six replicates. Then, sampled materials were kept for 90 days at room temperature (about $20^{\circ} \mathrm{C}$ to $26^{\circ} \mathrm{C}$ ). Each treatment group had six replicates.

The experimental treatments were as follows: i) positive control (NF, non-frozen and no additive), ii) negative control (F, frozen and no additive), iii) $\mathrm{F}+5 \%$ molasses (FM), iv) F+lactic acid bacteria (FLAB, $1.5 \mathrm{~g} / \mathrm{ton}$, consisting of Lactobacillus plantarum and Enterococcus faecium applied at a rate of $6.00 \log 10 \mathrm{cfu} \mathrm{LAB} / \mathrm{g}$ of material, Pioneer 1174, DuPont Pioneer, Johnston, IA, USA) (5) F+LAB and enzyme mixture (FLEN, 2 g/ton, Lactobacillus plantarum bacterium $(6.00 \log 10 \mathrm{cfu} / \mathrm{g})$ and cellulose $(150,000$ carboxymethyl cellulose unit $/ \mathrm{kg})$ and amylase (200,000 Sandstedt, Kneen, and Blish (SKB)/kg) enzymes, Silaid WS, Global Nutritech Co., Richmond, VA, USA).

\section{Chemical analyses}

At the end of the 90-day ensilage period, samples were taken for chemical and nutritional analyses. For $\mathrm{pH}$ measurements, $25 \mathrm{~g}$ of silage samples were taken into a beaker and $100 \mathrm{ml}$ distilled water was added. Then the mixture was mixed in a blender for 5 minutes and resultant mixture was filtered through Whatman filter paper and $\mathrm{pH}$ measurements were performed on this filtrate (Akyildiz, 1986). The dry matter (DM, AOAC, 2000 Method 934.01), crude ash (CA, AOAC, 2000, Method 942.05). Crude protein (CP, AOAC, 1996, Method 954.01), crude fiber (CF, AOAC, 1996, Method 978.10) and ether extract (EE, AOAC, 2000, Method 920.39) were determined in accordance with the methods specified in AOAC (1996, 2000). Neutral detergent fiber (NDF) was analyzed with heat-stable amylase and without Na-sulfite, acid detergent fiber (ADF) and acid detergent lignin (ADL) were determined according to the sequential method of Van Soest et al. (1991) by an ANKOM fiber analyzer (ANKOM 220 Technology, Macedon, NY, USA), and expressed inclusive of residual ash. Hemicellulose was defined as NDF - ADF.

The fleig point (FP) was calculated with the equation of $\mathrm{FP}=220+(2 \times \mathrm{DM} \%-15)-40 \times \mathrm{pH}$ (Akyildiz, 1986). The TDN were calculated according to the equation proposed by Chandler (1990), where TDN\% $=105.2-0.68 \times \mathrm{NDF} \%$. The non-fiber carbohydrates (NFC) were calculated by the equation proposed by Weiss et al. (1992): NFC $\%=100$ $(\mathrm{NDF} \%+\mathrm{CP} \%+\mathrm{EE} \%+\mathrm{CA} \%)$. Total carbohydrates (TC) were determined according to Sniffen et al. (1992) with the equation $\mathrm{TC} \%=100-(\mathrm{CP} \%+\mathrm{EE} \%+\mathrm{CA} \%)$. The metabolizable energy (ME) was calculated by the equation proposed by Robinson et al. (2004): $\mathrm{ME}=14.03-(0.01386 \times \mathrm{CF} \%)$ $(0.1018 \times \mathrm{CA} \%)$

To determine water soluble carbohydrate (WSC) content, liquid extractions were prepared with $40 \mathrm{~g}$ silage. Samples were placed into a beaker, $360 \mathrm{~mL}$ distilled water was added and mixed in a blender. The resultant slurry was filtered through Whatman 54 filter paper and then centrifuged. Samples were stored at $-20^{\circ} \mathrm{C}$ until the analyses. The WSC of samples was determined by phenol sulfuric acid method (Dubois et al., 1956).

The lactic acid (LA) was determined by the colorimetric method of Barker and Summerson (1941) and volatile fatty acid analyses (Fussell, 1987) (acetic [Chem Service O-4], propionic [Chem Service O-25] and butyric acid [Chem Service O-5]) were carried out in a gas chromatograph (Shimadzu GC-2010+, Kyoto, Japan) with a capillary column $(30 \mathrm{~m} \times 0.25 \mathrm{~mm} \times 0.25 \mu \mathrm{m}$, Restek) and with flame 
ionization dedector over a temperature range of $45^{\circ} \mathrm{C}$ to $230^{\circ} \mathrm{C}$.

In vitro dry matter digestibility (IVDMD) was determined in accordance with Tilley and Terry (1963). The rumen fluid was obtained from a steer slaughtered at a local slaughterhouse. All treatment groups were analyzed with the same rumen fluid. After incubation (Daisy incubator, ANKOM Technology, Macedon, NY, USA), sealed bags were extracted sequentially with neutral detergent solution (without either alpha-amylase or sodium sulfite) to determine the amount of undigested NDF remaining in each bag.

\section{Statistical analysis}

Data were analyzed using the general linear model procedure of the SPSS (1998). Differences between reported means were determined using Duncan's multiple range tests with a 5\% level of probability. The results of statistical analysis were presented as mean values and standard error of the means in tables.

\section{RESULTS AND DISCUSSION}

\section{Effects on chemical composition}

The effects of freezing and supplementation of molasses, $\mathrm{LAB}$ and $\mathrm{LAB}+$ enzyme on chemical composition are provided in Table 1. The data revealed the greatest DM content in group $\mathrm{F}$ and the least DM content in group NF. The CA, NDF, and ADL values of group F were also higher than group NF $(\mathrm{p}<0.05)$. Kohn and Allen (1992) investigated the effects of freezing at $-25^{\circ} \mathrm{C}$ for 12 months on quality of lucerne silage and reported significant decreases $(p<0.05)$ in dry matter content of silage samples with freezing. The $\mathrm{pH}$ has an important effect on silage mass conservation and its decline is due primarily to the production of LA from bacteria action on soluble carbohydrates. The $\mathrm{pH}$ value of group $\mathrm{F}$ was also higher than group NF $(p<0.05)$. Park et al. (2002) reported that there were no significant differences between Near Infrared Spectrophotometer (NIRS) predictions for freezing treatments and the reference predictions $(\mathrm{pH}, 3.50$ to 5.25; mean 4.18). The NDF contents of groups NF and $\mathrm{F}$ were respectively found to be $37.11 \%$ and $39.62 \%$. In a study conducted to investigate the chemical composition of fresh and frozen lucerne silage, Kohn and Allen (1992) reported significant increases in NDF and ADF contents of the samples with freezing. However, Deinum and Maassen (1994) reported that freezing fodder radish, lucerne, Italian ryegrass and maize silage at $-20^{\circ} \mathrm{C}$ for 244 days, thawing and subsequent freeze-drying cycles had little effect on chemical composition. The ADL contents of groups NF and F were respectively found to be $11.87 \%$ and $12.33 \%$. The average of ADL values of group F and NF was $12.10 \%$.

The $\mathrm{pH}$ of group NF (3.55) was lower than those of $\mathrm{F}$ and $\mathrm{F}+$ supplemented groups (varied between 4.21 and 4.26) $(p<0.01)$. However, there were no significant differences among the frozen groups. Meeske et al. (1993) reported that when $\mathrm{LAB}$ and $\mathrm{LAB}+$ enzyme were used in the sorghum silage, $\mathrm{pH}$ dropped rapidly compared to the control group. Silage quality is highly related to DM content of silage. In this experiment, DM contents of the groups varied between $29.40 \%$ and $35.51 \%$ and the effects of supplements were found to be significant $(\mathrm{p}<0.01)$. The DM content of silages was lower in group NF than in groups F and FM, FLAB and FLEN. The DM content of group FM was higher than those of groups FLAB and FLEN but similar with group F. The DM content of FLAB group was lower than those of $F$ and FLEN groups. On the other hand, Koc et al. (2009) and

Table 1. The effects of freezing, molasses, LAB and LAB+enzyme supplementation on chemical composition of sunflower silage

\begin{tabular}{|c|c|c|c|c|c|c|c|}
\hline \multirow{2}{*}{ Parameters } & \multicolumn{5}{|c|}{ Treatments $^{1}$} & \multirow{2}{*}{ SEM } & \multirow{2}{*}{$\mathrm{p}$} \\
\hline & $\mathrm{NF}$ & $\mathrm{F}$ & FM & FLAB & FLEN & & \\
\hline$\overline{\mathrm{pH}}$ & $3.55^{\mathrm{Bb}}$ & $4.26^{\mathrm{Aa}}$ & $4.23^{\mathrm{a}}$ & $4.24^{\mathrm{a}}$ & $4.21^{\mathrm{a}}$ & 0.07 & $* *$ \\
\hline DM (\%) & $29.40^{\mathrm{Bd}}$ & $34.74^{\mathrm{Aab}}$ & $35.51^{\mathrm{a}}$ & $31.89^{c}$ & $33.65^{\mathrm{b}}$ & 0.53 & $* *$ \\
\hline $\mathrm{CP}(\% \mathrm{DM})$ & $7.96^{\mathrm{Aa}}$ & $7.94^{\mathrm{Aa}}$ & $7.96^{\mathrm{a}}$ & $6.33^{b}$ & $7.27^{\mathrm{a}}$ & 0.19 & $*$ \\
\hline $\mathrm{CA}(\% \mathrm{DM})$ & $13.44^{\mathrm{Ba}}$ & $13.63^{\mathrm{Aa}}$ & $12.72^{\mathrm{a}}$ & $10.05^{\mathrm{b}}$ & $13.72^{\mathrm{a}}$ & 0.37 & $* *$ \\
\hline $\mathrm{EE}(\% \mathrm{DM})$ & 5.23 & 4.53 & 4.35 & 5.36 & 4.58 & 0.17 & NS \\
\hline $\mathrm{CF}(\% \mathrm{DM})$ & $20.56^{\mathrm{Ab}}$ & $21.94^{\mathrm{Aab}}$ & $19.16^{\mathrm{b}}$ & $22.90^{\mathrm{a}}$ & $21.53^{\mathrm{ab}}$ & 0.42 & $*$ \\
\hline NDF (\% DM) & $37.11^{\mathrm{Bbc}}$ & $39.62^{\text {Aab }}$ & $35.70^{\mathrm{c}}$ & $42.14^{\mathrm{a}}$ & $39.82^{\mathrm{a}}$ & 0.620 & $* *$ \\
\hline $\mathrm{ADF}(\% \mathrm{DM})$ & $32.43^{\mathrm{Abc}}$ & $34.27^{\mathrm{Aab}}$ & $30.81^{\mathrm{c}}$ & $36.41^{\mathrm{a}}$ & $34.92^{\mathrm{a}}$ & 0.540 & $* *$ \\
\hline HEM (\% DM) & $4.68^{\mathrm{B}}$ & $5.35^{\mathrm{A}}$ & 4.89 & 5.73 & 4.90 & 0.23 & NS \\
\hline ADL (\% DM) & $11.87^{\mathrm{B}}$ & $12.34^{\mathrm{A}}$ & 11.66 & 13.51 & 13.39 & 0.360 & NS \\
\hline
\end{tabular}

LAB, lactic acid bacteria; SEM, pooled standard error of means; $p$, probability; DM, dry matter; CP, crude protein; CA, crude ash; EE, ether extract; CF, crude fiber; NDF, neutral detergent fiber; ADF, acid detergent fiber; HEM, hemicellulose; ADL, acid detergent lignin.

${ }^{1} \mathrm{NF}$, non-frozen; F, frozen; FM, Frozen+\% $\%$ molasses; FLAB, frozen+LAB; FLEN, frozen+LAB+Enzyme.

$* \mathrm{p}<0.05 ; * * \mathrm{p}<0.01 ; \mathrm{NS}$, not significant.

a,b,c,d Values with different superscript in a line differ significantly between treatment groups.

$\mathrm{A}, \mathrm{B}$ Values with different superscript in a line differ significantly between freezing treatment. 
Kamarloiy and Teimouri Yansari (2008) reported that addition of LAB to sunflower silage did not change the silage dry matter content. Considering the frozen groups, some water leakage and thus increased DM contents were observed in F, FM, FLAB, and FLEN groups. Martino and Zaritzky (1988) reported that water loss through thawing and dehydration with water-soluble substances may alter DM contents of the foods. Especially during freezing, intracellular and extracellular water expands and the cell wall is broken. Then, tissue integrity of frozen plants is destroyed and intracellular and extracellular water will be unbound and leak outside the tissue and drip loss will occur. $\mathrm{CP}$ content of FLAB group was lower than those of the other groups $(\mathrm{p}<0.05)$. On the other hand, $\mathrm{CP}$ content of NF, F, FM, and FLEN groups were similar. LAB inoculation might have increased bacterial growth, fermentation, required protein or nitrogen source of silage and consumed by the microorganisms. The LAB generally need various amino acids and vitamins for growth (Pahlow et al., 2003). It is assumed that bacterial growth would increase via $\mathrm{LAB}$ inoculation to silage during the ensiling process and therefore it would reach a better fermentation and consequently better silage quality. On the other hand, lipid oxidation, enzymatic esterification, protein degradation and change may occur with the freezing of foods (Fennoma and Powrie, 1963). Some experimental results revealed that sunflower silage protein ratio may vary between $11.60 \%$ and $13.45 \%$ (Tan et al., 2015). However many factors such as cultivar, harvest time and fertilization may also affect the protein content of sunflower silages (Demirel et al., 2006).
The CA of silages was significantly affected by the treatments $(p<0.05)$ and CA ratio of the LAB treatment group was lower than those of the other groups. Also LAB treatment lowered, DM and CP compared to the other groups. These results may be due to decreasing protein and ash contents and increasing fermentable carbohydrate ratio of silages (Mehmet, 2006). On the other hand, crude ash is related to mineral content of feeds. Exposure of feeds to freeze-thaw processes may result in water leakage and consequently minerals losses from the silage. There was no significant differences among the treatment groups in terms of ether extract ratio ( $p>0.05)$. Koc et al. (2009) reported that LAB and enzyme inoculants did not affect silage ether extract in sunflower silages.

\section{Effects on fermentation and nutritive value}

The effects of freezing and supplementation of molasses, $\mathrm{LAB}$ and LAB+enzyme on IVDMD, fermentation metabolites and nutritive value of sunflower silages is provided in Table 2 . The $\mathrm{OM}$ was influenced negatively by freezing treatment at $-20^{\circ} \mathrm{C}$. Also TDN, NFC, and ME were negatively affected by freezing treatment. Such results were probably because of the loss of easily soluble carbohydrates during the thawing of frozen material. There was also a significant decrease in IVDM digestibility of silage in the freezing group which might be due to higher levels of cell wall components (especially ADL content) in the freezing group. Fleig points of the treatment groups were not significantly different from each other ( $p>0.05)$. The FP of group NF and $\mathrm{F}$ was respectively determined as 121.80 and

Table 2. The effects of freezing, molasses, LAB and LAB+enzyme supplementation on IVDMD, fermentation metabolites and nutritive value of sunflower silages

\begin{tabular}{|c|c|c|c|c|c|c|c|}
\hline \multirow{2}{*}{ Parameters } & \multicolumn{5}{|c|}{ Treatments $^{1}$} & \multirow{2}{*}{ SEM } & \multirow{2}{*}{$\mathrm{p}$} \\
\hline & NF & $\mathrm{F}$ & FM & FLAB & FLEN & & \\
\hline IVDMD (\%) & $77.85^{\mathrm{Aa}}$ & $72.89^{\mathrm{Bb}}$ & $77.92^{\mathrm{a}}$ & $71.49^{b}$ & $70.56^{\mathrm{b}}$ & 0.822 & $* *$ \\
\hline TDN (\% DM) & $79.96^{\mathrm{Aab}}$ & $78.26^{\mathrm{Bbc}}$ & $80.93^{\mathrm{a}}$ & $76.55^{\mathrm{c}}$ & $78.13^{\mathrm{c}}$ & 0.420 & $* *$ \\
\hline $\mathrm{OM}(\% \mathrm{DM})$ & $86.56^{\mathrm{Ab}}$ & $86.37^{\mathrm{Bb}}$ & $87.28^{\mathrm{b}}$ & $89.95^{\mathrm{a}}$ & $86.28^{\mathrm{b}}$ & 0.370 & $* *$ \\
\hline NFC (\% DM) & $36.27^{\mathrm{Ab}}$ & $34.28^{\mathrm{Bb}}$ & $39.28^{\mathrm{a}}$ & $36.12^{\mathrm{b}}$ & $34.61^{\mathrm{b}}$ & 0.540 & $*$ \\
\hline $\mathrm{TC}(\% \mathrm{DM})$ & $73.38^{\mathrm{Ab}}$ & $73.90^{\mathrm{Ab}}$ & $74.97^{\mathrm{b}}$ & $78.26^{\mathrm{a}}$ & $74.43^{\mathrm{b}}$ & 0.520 & $*$ \\
\hline ME (Mcal/kg DM) & $12.38^{\mathrm{Ab}}$ & $12.34^{\mathrm{Bb}}$ & $12.47^{\mathrm{b}}$ & $12.69^{\mathrm{a}}$ & $12.34^{\mathrm{b}}$ & 0.040 & $* *$ \\
\hline FP & $121.80^{\mathrm{Aa}}$ & $104.18^{\mathrm{Bbc}}$ & $107.03^{\mathrm{b}}$ & $99.28^{c}$ & $103.80^{\mathrm{c}}$ & 1.980 & $* *$ \\
\hline WSC (\% DM) & $2.43^{\mathrm{Ab}}$ & $2.65^{\mathrm{Bb}}$ & $3.20^{\mathrm{a}}$ & $2.50^{\mathrm{b}}$ & $2.69^{\mathrm{b}}$ & 0.06 & $* *$ \\
\hline LA $(\% \mathrm{DM})$ & $3.52^{\mathrm{B}}$ & $4.64^{\mathrm{A}}$ & 3.77 & 5.01 & 3.16 & 0.37 & NS \\
\hline $\mathrm{AA}(\% \mathrm{DM})$ & $1.34^{\mathrm{B}}$ & $1.62^{\mathrm{A}}$ & 1.55 & 2.47 & 0.94 & 0.23 & NS \\
\hline PA $(\% \mathrm{DM})$ & $0.34^{\mathrm{Aa}}$ & $0.09^{\mathrm{Bbc}}$ & $0.01^{\mathrm{c}}$ & $0.02^{\mathrm{bc}}$ & $0.19^{\mathrm{ab}}$ & 0.03 & $*$ \\
\hline $\mathrm{BA}(\% \mathrm{DM})$ & ND & ND & ND & ND & ND & - & - \\
\hline LA/AA & $2.63^{\mathrm{A}}$ & $2.86^{\mathrm{A}}$ & 2.43 & 2.03 & 3.36 & 0.08 & NS \\
\hline
\end{tabular}

LAB, lactic acid bacteria; IVDMD, in vitro dry matter digestibility; SEM, pooled standard error of means; $p$, probability; TDN, total digestible nutrients; DM, dry matter; OM, organic matter; NCF, non-fiber carbohydrates; TC, total carbohydrates; ME, metabolisable energy; FP, fleig point; WCS, water soluble carbohydrate; LA, lactic acid; AA, acetic acid; PA, propionic acid; BA, butyric acid; ND, not detected.

${ }^{1} \mathrm{NF}$, non-frozen; F, frozen; FM, frozen+\% 5 molasses; FLAB, frozen+LAB; FLEN, frozen+LAB+enzyme.

$* \mathrm{p}<0.05 ; * * \mathrm{p}<0.01 ; \mathrm{NS}$, not significant.

a,b,c Values with different superscript in a line differ significantly between treatment groups.

A, B Values with different superscript in a line differ significantly between freezing treatment. 
104.18 (Table 2). The quality of sunflower silages (104.18 and 121.80) was assessed as "good quality" (Akyildiz, 1986). The WSC content of group NF $(2.65 \%)$ was higher than group F (2.43\%). Freezing and subsequent thawing result in severe water loss and seepage of water-soluble substances. Particularly, loss of carbohydrates after thawing causes decrease in TDN of the feeds (Martino and Zaritzky, 1988). The propionic acid (PA) concentration of group NF $(0.337 \%)$ was higher than that of group F $(0.09 \%)$. The propionic acid content is an important parameter for silage quality. Propionic acid may improve the aerobic stability of corn silages (Britt and Tuber, 1975).

Addition of $\mathrm{LAB}$ caused an increase in $\mathrm{CF}$ ratio in supplemented groups compared to NF and FM groups $(p<0.05)$. The NDF and ADF ratios were higher in FLAB and FLEN groups than in NF and FM groups. Hemicellulose and ADL ratios of treatment groups were not significantly different ( $\mathrm{p}>0.05)$. Martino and Zaritzky (1988) noted that freezing and thawing may alter cellulose content of feeds. According to Tan et al. (2015), the NDF and ADF values of sunflower silage may vary between $55.85 \%$ $57.62 \%$ and $37.81 \%-43.09 \%$, respectively. In this study, these values varied between $35.70 \%-42.14 \%$ and $30.81 \%$ $36.41 \%$, respectively. Fennoma and Powrie (1963) reported that freezing may change the cellulose content of foods. Koc et al. (2009) indicated that LAB inoculation decreased cellulose content of sunflower silages compared to the control group. Some studies showed that $\mathrm{LAB}+\mathrm{E}$ mixture inoculation reduced the cell wall contents of silages (Nadeau et al., 2000). Ozduven et al. (2009) reported that $\mathrm{LAB}+\mathrm{E}$ mixture addition decreased the NDF ratio of silage compared to control and LAB inoculant groups. However, the in vitro dry and organic matter digestibility of the silages was not affected by the treatments. The freezing process caused a decrease in IVDMD value of the treatment groups compared to NF group. Within the freezing groups, only in the FM group, IVDMD value was similar to the NF group and this group's IVDMD value was higher than those of the FLAB and FLEN groups $(\mathrm{p}<0.01)$. There is not enough experimental data about frozen silage material and the effect of LAB inoculation in the literature. Demirel et al. (2006) reported that $\mathrm{OM}$ digestibility of $\mathrm{LAB}+\mathrm{E}$ silages could be increased by decreasing NDF in silage materials. In this experiment, lower NDF and ADF content of groups (NF, FM groups) correlated with an increase in in vitro DM digestibility of silage. There is a positive correlation between in vitro dry matter digestibility and low cell wall components of forages. It is expected that inoculation of cell wall degrading enzymes in silage may improve concentration of WSC available to LAB, and after appropriate fermentation, increase the digestibility of $\mathrm{OM}$ and fiber (Xing et al., 2009). On the other hand, some other studies showed that $\mathrm{LAB}$ and LAB+enzyme inoculants provided an improvement in digestibility or degradability of silage DM (Kamarloiy and Teimouri Yansari, 2008).

The highest TDN (80.93) and NFC (39.28) contents were determined in the FM group. Silage OM significantly differed among groups $(\mathrm{p}<0.05)$ and the highest OM was found in the FLAB group (89.95). The OM of feed is related to crude ash content. In this experiment, in the FLAB group, DM was high and CA was low, therefore OM content was higher than in other treatment groups. The FP was the highest in the NF group (121.80) and the lowest in the FLAB group (99.28) $(\mathrm{p}<0.001)$. The FP of silages were calculated based on the $\mathrm{pH}$ and dry matter content of silages. This value coincides with the "excellent" quality according to the Fleig scoring system.

WSC content of the FM group was significantly higher than those of the other groups $(\mathrm{p}<0.01)$. PA concentration of the NF group was higher than those of the other groups $(p<0.05)$. There were no significant differences among the groups in terms of LA, AA, and LA/AA. The BA was not detected in silage samples. It is generally reported that microbial inoculation of silage had a positive effect on silage fermentation. When forages are inoculated with LAB and $\mathrm{LAB}+\mathrm{E}$ before ensiling, resulting silage usually has a lower $\mathrm{pH}$ and a higher concentration of LA, but lower concentrations of acetic acid than control silage (Kung et al., 1987). Ozduven et al. (2009) reported that sunflower silage treated with $\mathrm{LAB}$ and $\mathrm{LAB}+\mathrm{E}$ mixture inoculants had lower $\mathrm{pH}$ and acetic acid contents than that of control silage and a higher LA concentration and LA/acetic acid ratio than that of control silages.

\section{CONCLUSION}

The freezing treatments caused significant changes in nutrient composition of sunflower silage. The freezing caused an increase in dry matter content of silage due to loss of water after thawing the silage material and decreased the WSC contents of samples. In this case, this resulted in reduction of TDN of the feed (OM, TDN, NFC, and IVDMD are decreased) and subsequently resulted in energy and carbohydrates losses (ME is reduced). In conclusion, while molasses supplementation improved some quality traits of frozen silage, $\mathrm{LAB}$ and $\mathrm{LAB}+$ enzyme inoculations were not found to be effective to compensate for the negative impacts of freezing on sunflower silage.

\section{CONFLICT OF INTEREST}

We certify that there is no conflict of interest with any financial organization regarding the material discussed in the manuscript. 


\section{REFERENCES}

Akyildiz, A. R. 1986. Feed Science and Technology. Agricultural Faculty Publications (Ankara University, Publication no:895), Ankara, Turkey. 974 p.

AOAC. 1996. Official Methods of Analysis of AOAC International. 16th edition. Gaithersburg, MD, USA.

AOAC. 2000. Official Methods of Analysis of AOAC International. 17th edition Gaithersburg, MD, USA.

Barker, S. B. and W. H. Summerson. 1941. The colorimetric determination of lactic acid in biological material. J. Biol. Chem. 138:535-554.

Britt, D. G. and J. T. Huber. 1975. Fungal growth during fermentation and refermentation of nonprotein nitrogen treated corn silage. J. Dairy. Sci. 58:1666-1671.

Chandler, P. 1990. Energy prediction of feeds by forage testing explorer. Feedstuffs 62:12.

Deinum, B. and A. Maassen. 1994. Effects of drying temperature on chemical composition and in vitro digestibility of forages. Anim. Feed Sci. Technol. 46:75-86.

Demirel, M., D. Bolat, S. Celik, Y. Bakici, and A. Tekeli. 2006. Evaluation of fermentation qualities and digestibility of silages made from sorghum and sunflower alone and the mixtures of sorghum-sunflower. J. Biol. Sci. 6:926-930.

Dubois, M., K. A. Gilles, J. K. Hamilton, P. A. Rebers, and F. Smith. 1956. Calorimetric method for determination of sugars and related substances. Anal. Chem. 28:350-356.

Fennoma, O. and W. D. Powrie. 1963. Fundamentals of lowtemperature food preservation. Adv. Food Res. 13:219-347.

Fussell, R. J. and D. V. McCalley. 1987. Determination of volatile fatty acid $\left(\mathrm{C}_{2}-\mathrm{C}_{5}\right)$ and lactic acid in silage by gas chromatography. Analyst 122:1213-1216.

George, R. M. 1993. Freezing proceseses used in the food industry. Trends Food Sci. Technol. 4:134-138.

Gleadow, R. M., M. E. Møldrup, N. H. O'Donnell, and P. N. Stuart. 2012. Drying and processing protocols affect the quantification of cyanogenic glucosides in forage sorghum. J. Sci. Food Agric. 92:2234-2238.

Kamarloiy, M. and A. Teimouri Yansari. 2008. Effect of microbial inoculants on the nutritive value of corn silage for beef cattle. Pakistan J. Biol. Sci. 11:1137-1141.

Koc, F., M. L. Ozduven, L. Coskuntuna, and C. Polant. 2009. The effects of inoculant lactic acid bacteria on the fermentation and aerobic stability of sunflower silage. Poljoprivreda 15:47-52.

Kohn, R. A. and M. S. Allen. 1992. Storage of fresh and ensiled forages by freezing affects fibre and crude protein fractions. J. Sci. Food Agric. 58:215-220.

Kung, L., L. D. Satter, B. A. Jones, K. W. Genin, A. L. Sudoma, G. L. Enders, and H. S. Kim. 1987. Microbial inoculation of low moisture alfalfa silage. J. Dairy Sci. 70:2069-2077.

Martino, M. N. and N. E. Zaritzky. 1988. Ice crystal size modifications during frozen beef storage. J. Food Sci. 53:1631-1637.
Meeske, R., G. Ashbell, Z. G. Weinberg, and T. Kipnis. 1993. Ensiling forage sorghum at two stages of maturity with the addition of lactic acid bacterial inoculants. Anim. Feed Sci. Technol. 43:165-175.

Mehmet, A. B. 2006. Effects of hybrid type, stage of maturity, and fermentation length on whole plant com silage quality. Turk. J. Vet. Anim. Sci. 30: 331-336.

Nadeau, E. M. G., D. R. Buxton, J. R. Russell, M. J. Allison, and J. W. Young. 2000. Enzyme, bacterial inoculant, and formic acid effects on silage composition of orchardgrass and alfalfa. J. Dairy Sci. 83:1487-1502.

Ozduven, M. L., F. Koc, C. Polat, and L. Coskuntuna. 2009. The effects of lactic acid bacteria and enzyme mixture inoculants on fermentation and nutrient digestibility of sunflower silage. Kafkas Univ. J. Fac. Vet. Med. Vet. Fak. Derg. 15:195199.

Pahlow, G., R. E. Muck, F. Driehuis, S. J. O. Elferink, and S. F. Spoelstra. 2003. 2 Microbiology of Ensiling. Silage Sci. Tech. 42:31.

Park, R. S., R. E. Agnew, and D. J. Kilpatrick. 2002. The effect of freezing and thawing on grass silage quality predictions based on near infrared reflectance spectroscopy. Anim. Feed Sci. Technol. 102:151-167.

Robinson, P. H., D. I. Givens, and G. Getachew. 2004. Evaluation of NRC, UC Davis and ADAS approaches to estimate the metabolizable energy values of feeds at maintenance energy intake from equations utilizing chemical assays and in vitro determinations. Anim. Feed Sci. Technol. 114:75-90.

Sniffen, C. J., J. D. O'connor, P. J. Van Soest, D. G. Fox, and J. B. Russell. 1992. A net carbohydrate and protein system for evaluating cattle diets: II. Carbohydrate and protein availability. J. Anim. Sci. 70:3562-3577.

Speck, M. L. and B. Ray. 1977. Effects of freezing and storage on microorganisms in frozen foods: A review. J. Food Protec. 40: 333-336

SPSS. 1998. Version 17.00 for Windows. SPSS Inc., Chicago, IL, USA.

Tan, M., H. Yolcu, and Z. D. Gül. 2015. Nutritive value of sunflower silages ensiled with corn or alfalfa at different rate. J. Agric. Sci. 21:184-191.

Tilley, J. M. A. and R. A. Terry. 1963. A two-stage technique for the in vitro digestion of forage crops. J. Br. Grassl. Soc. 18: 104-111.

Van Soest, P. H., J. B. Robertson, and B. A. Lewis. 1991. Methods for dietary fiber, neutral detergent fiber, and nonstarch polysaccharides in relation to animal nutrition. J. Dairy Sci. 74: 3583-3597.

Weiss, W. P., H. R. Conrad, and N. R. Pierre. 1992. A theoretically-based model for predicting total digestible nutrient values of forages and concentrates. Anim. Feed Sci. Technol. 39:95-110.

Xing, L., J. Chen, and L. J. Han. 2009. The effect of an inoculant and enzymes on fermentation and nutritive value of sorghum straw silages. Bioresour. Technol. 100:488-491. 